\title{
Social Change Demolishing Secular Attitude among
}

\section{Indian Youngsters}

\author{
Mr. Vinod Kamble ${ }^{1 *}$
}

\section{ABSTRACT}

Indian society is rapidly changing in accordance to cultural, social, moral and political values. India is known as second largest democratic country in the world. The roots of democracy in Indian people have been strongly established since the struggle of Indian independence. Sociopolitical environment have been changing from last decade. On this background it was hypothesized that social change negatively related to secular attitude. For this study 100 students were selected from different colleges. The social change inventory and secular attitude scale was administered on participated students. The results does not confirm the hypotheses in this study. The social change issue and importance of secular attitude has elucidated in the present paper.

Keywords: Social Change, Secular Attitude, Indian Youngsters, Gender.

The great psychologist Guatam Buddha said that Change is the law of nature. Therefore social change takes place all over the world. Today we seen a drastic change in Indian political, social, educational, economical, moral and other various social aspects. After independence social change in India is very significant. Indian society trying to abolish old and traditional customs i.e. untouchability, caste discrimination, childhood marriages, SATI, slavery etc. In this way Indian society is gradually forward to modernization.

Social change may be defined, the process in which there is some significant alteration in the structure and function of the social systems (Kuppuswamy, 1979). Social change also refers to the modification of behaviour or change in the attitudes of a large number of individuals, alteration of customs, values, institutions and social behaviour. Social change is meant only such alterations as occur in social organizations that is structure and functions of society (Devis, 1960). Social change is a complex and multidimensional. If one aspect changed, it affects other aspect of social life. So it is desirable to take an integrated view of the processes of social change. Social change leads to the perfection of a society as well as a nation. The advancement

\footnotetext{
${ }^{1}$ Asst. Professor, Dept. of Psychology, P. V. P. Mahavidyalaya, Kavathe Mahankal. Sangli, MS, INDIA *Responding Author

(C) 2016 I V Kamble; licensee IJIP. This is an Open Access Research distributed under the terms of the Creative Commons Attribution License (http://creativecommons.org/licenses/by/2.0), which permits unrestricted use, distribution, and reproduction in any Medium, provided the original work is properly cited.
} 
of science and technology has completely changed Indian society not only in the form of social structure but in the form of living and way of thinking. Today even in the rural area, people utilize electric and modern scientific techniques in agriculture, farmers uses mobile phones and takes information about weather by use of internet. School students and housewives also use computers, laptops, mobiles and internet. They are connected to world, and their life becomes informative. India is one of the familiar countries who uses of modern technology in the world.

Aziz et.al. (2012) examined the effects of urbanization towards social and cultural changes among Malaysian settlers in the Federal Land Development schemes (FELDA). They found that Urbanization will change their social and cultural lives. Urbanization could benefit all FELDA settlers current and future generation by improving their living status. Hashim et.al. (2012) studied literature and social change. They concluded that the students are capable of identifying issues which can bring about social change in their communities. Sankpal (2012) investigated the social change among unmarried male and female post-graduate students. He concluded that there is no significant difference between male and female regarding to social change. Cadez (2013) studied social change, institutional pressures and knowledge creation. He concluded that radical social change was not mirrored by such change in normative institution, where as recent changes in regulatory institution seem to have a substantial positive effect on research performance.

Secularism emerged in the west as a movement challenged the authority of the Catholic Church. But in India secularism take place in $5^{\text {th }}$ B.C. when Charvak, Buddhism and Jainism started their movements. Guatam Buddha denied God, Atman, Veda and predestination and established a secular way of life means DHAMMA. So Guatam Buddha was the founder of secularism in India (Naik, 2013). After independence India adopted secularism as a state policy. The Indian Constitution guarantees freedom of conscience, freedom to profess, practice and propagate religion and also freedom to establish religious institutions and manage or administer their affairs. A Secular State means that the one that protects all religions equally and does not uphold any religion as the state religion. The state observes an attitude of neutrality and impartiality towards all religions. Oxford Advanced Learners Dictionary (2000) defined the term secularism, as belief that morality and education etc. should not be based on religion. Donald E. Smith did not define secular state that, a state which guarantees individual and corporate freedom of religion, deals with the individual as a citizen irrespective of his religion, is not constitutionally connected to a particular religion, nor does it seek to promote or interfere with religion. Secularism is a belief that polity, education, morality and culture must be free from religion (Holyoake, 1896).

Secularism is a sign of modernity, plurality, co existence, rationalism and developing with a fast growing multicultural society. By the process of secularization Indian social life most affected i.e. increasing mobility, dowry prohibition, eradication of untouchability, remarriages, inter-caste marriages, equal justice of women and castes takes place etc. Thus it is said that rites and rituals 
connected with life cycle of Indians are undergoing important changes. Now Indians are moving from religiosity to a secular way of life.

Sumbul (2002) investigates the secular attitude of the students studying in two denominational schools. The investigator found that Muslim and Non-Muslim students are not significantly different on secular attitude. Kaul (2010) search the impact of education on secularism. The researcher found that socio-economic status variates the degree of secularism significantly. Magalingam and Visvanathan (2011) examined the secular attitude and attitude towards discipline among the professional college students in relation to selected variables. The researcher found that professional college students are highly favourable and male-female students differ significantly in their secular attitude. Naik (2012) studied influence of gender and religion on secular attitude among college professors. He found that males are having more secular attitude than females. Ashrafi and Govil (2013) measured secular attitude of undergraduate students. Their study revealed that undergraduate students belonging to Muslim and Non-Muslim communities significantly different in the secular attitude. Ali and Kishore (2014) studied secular attitude of Madarsa students. They found that all selected madarsa student's posses' secular attitude of average level and there is no gender difference. Subramanyan and Ajith Kumar (2014) concluded that the ideology of secularism is facing severe criticism due to the pseudo secularist nature of Indian Polity. Religious fundamentalism has resulted in the weakening of democratic and human rights values, no one has come forward to combat pseudo secularism in Indian Polity.

India is a country of diversity in religions, castes, languages, realm, culture etc., but unity is there. Acceptance of all religions and different ways of life is the cornerstone of the Indian culture, heritage and polity; but the nature of secular mode in Indian polity has been declining day by day. Indian secular polity threatened by caste discrimination, communalism, religious fundamentalism, separatism and violence. Bhargava (1998) has highlighted the practical aspects of religion and secularism in India. He interpreted that Indian polity spoil the core values of real secular values and euphemistic attitude of secularism emerged.

As far as Nirbhaya case is concerned with rape, and women are going to suffer mostly. They cannot get equality but receive only atrocities. Society cannot give permission to inter-caste and inter-religious marriages, and when it happen Honour Killing take place. Even today, Dalit's are suffering by atrocities. Khairlanji Massacre (five people of one lower caste family killed by higher caste people) is a burning example of it. Minorities cannot be accepted in main stream. Khap Panchayati's (traditional brutal justice system) are still exist, their rules and regulations are disgracing to humanity. Every religion has their own T.V. channels, Newspapers, Schools and Institutions. Thereby they try to influence the people, particularly about their own religion. Children get education about their parent's religion non-scientifically since their childhood. Politicians are spreading a separate kind of anarchism by creating religious violence, caste estrangement and regionalism. Altogether, Indian society is hypocrite. Though by 
constitutionally Indians accepted secularism but they do not appear secular in practice. It means that though Indian society is changing positively but secular attitude is not accepted easily. Keeping all these views in consideration, the present study tried to search relation between social change and secular attitude in Indian youngsters.

\section{Aim:}

The main aim of the study is to find out the relation between social change and secular attitude among Indian youngsters.

\section{OBJECTIVES:}

1. To measure social change and find out whether male and female Indian youngsters differ significantly from each other or not.

2. To measure secular attitude and search whether male and female Indian youngsters differ significantly from each other or not.

3. To find out relationship between social change and secular attitude among Indian youngsters, and test whether the relationship is significant or not.

\section{Hypotheses:}

1. There is significant gender difference regarding to social change among Indian youngsters.

2. Level of secular attitude is high in male than female Indian youngsters.

3. Social change is significantly and negatively associated with secular attitude among Indian youngsters.

\section{METHODOLOGY:}

\section{Sample:}

The study was conducted on the sample of 100 youngsters from Sangli (Maharashtra, India). Random sampling method was used for selecting sample. Age range of the subject was 19 to 23 years and educational level was U.G. and P.G. Male-female ratio was 1:1.

\section{Psychological tools used for data collection:}

1. A Battery of Test Measuring Social Change: The battery was constructed and standardized by Rama Tiwari, Roma Pal and Radha Pandey. The battery consists of 42 items with 6 alternatives. The battery divided in six sub areas that is 1 . Inter-caste Migration 2. Position of Women 3. Free Choice of Mate 4. Family Planning 5. Intercaste Marriage 6. Social Mobility. Split-half reliability is $0.78(\mathrm{~N}-100)$ and test-retest reliability is $0.72(\mathrm{~N}-100)$. Validity coefficient is 0.79 .

2. Secular Attitude Scale: The scale was constructed and standardized by Anshu Mehra and Durganand Sinha. The scale consists of 35 items with 5 alternatives. The scale divided in four broad elements i.e. 1. Secular attitude and Religion 2. Secular attitude and Equality 3. Secular attitude and Rationality 4. Secular attitude and Identity. Split-half reliability coefficient is $0.92(\mathrm{~N}-236)$, Spearman-Brown reliability coefficient is $0.96(\mathrm{~N}-$ 236). 


\section{Statistical Treatment of the Data:}

The statistical techniques such as Mean, Standard Deviation, ' $t$ ' test and Pearson's Product Moment Correlation were used for interpretation of the data.

\section{Procedure of Data Collection:}

Sample of this study were collected from Sangli (Maharashtra, India) District. Firstly students called together in small groups and given instructions about tests. 10 minutes rest permitted them between 2 testes. Lastly collected all answer sheets of tests.

\section{RESULTS AND DISCUSSION:}

Table 1 - Mean, SD and 't' value of male and female towards Social Change

\begin{tabular}{|l|l|l|l|l|l|l|l|}
\hline Variable & Gender & N & Mean & SD & df & 't' value & $\begin{array}{l}\text { Level of } \\
\text { significance }\end{array}$ \\
\hline Social Change & Male & 50 & 200.16 & 19.35 & 98 & 1.17 & NS \\
\cline { 2 - 8 } & Female & 50 & 195.12 & 23.64 & & & \\
\hline
\end{tabular}

Table 1 shows that social change of 100 Indian male and female youngsters. The mean of male group is 200.16 with SD 19.35, while the mean of females group is 195.12 with SD 23.64. ' $t$ ' value of both groups is 1.17, which is not significant at 98 Degrees of Freedom. Thus the first hypothesis that, "There is significant gender difference regarding social change among Indian youngsters” is not accepted. This result does support result of Sankpal (2012).

Table 2 - Mean, SD and ' $t$ ' value of male and female towards Secular Attitude

\begin{tabular}{|l|l|l|l|l|l|l|l|}
\hline Variable & Gender & N & Mean & SD & df & 't' value & $\begin{array}{l}\text { Level of } \\
\text { significance }\end{array}$ \\
\hline $\begin{array}{l}\text { Secular } \\
\text { Attitude }\end{array}$ & Male & 50 & 118.02 & 14.79 & 98 & 0.14 & NS \\
\cline { 2 - 8 } & Female & 50 & 117.56 & 18.78 & & & \\
\hline
\end{tabular}

Table 2 shows that the level of secular attitude of male and female youngsters. The Mean and SD of male group is 118.02 and 14.79 , while females group is 117.56 and 18.78 respectively. On the basis of mean score it is concluded that males and females are having moderate secular attitude. With df 98, ' $t$ ' value of both groups is 0.14 , which is not significant. Thus the second hypothesis that, "Level of secular attitude is high in male than female Indian youngsters" is not accepted. This result corroborated the results of Ali and kishore (2014). But results of Magalingam and Visvanathan (2011) and Naik (2012) does not support present research result. 
Social Change Demolishing Secular Attitude among Indian Youngsters

Table 3 - Relationship between Social Change variables and Secular Attitude

\begin{tabular}{|l|l|l|l|l|l|l|l|l|}
\hline Variables & $\begin{array}{l}\text { Inter } \\
\text { Caste } \\
\text { Migration }\end{array}$ & $\begin{array}{l}\text { Position } \\
\text { of } \\
\text { Women }\end{array}$ & $\begin{array}{l}\text { Free } \\
\text { Choice } \\
\text { of Mate }\end{array}$ & $\begin{array}{l}\text { Family } \\
\text { Planning }\end{array}$ & $\begin{array}{l}\text { Inter- } \\
\text { caste } \\
\text { Marriage }\end{array}$ & $\begin{array}{l}\text { Social } \\
\text { Mobility }\end{array}$ & $\begin{array}{l}\text { Social } \\
\text { Change }\end{array}$ & Secular \\
\hline $\begin{array}{l}\text { Inter-Caste } \\
\text { Migration }\end{array}$ & 1 & $0.257^{* *}$ & $0.482^{* *}$ & $0.467^{* *}$ & $0.744^{* *}$ & $0.259^{* *}$ & $0.758^{* *}$ & $\mathbf{0 . 2 4 2}^{*}$ \\
\hline $\begin{array}{l}\text { Position of } \\
\text { Women }\end{array}$ & 1 & $0.332^{* *}$ & $0.457^{* *}$ & $0.266^{* *}$ & $0.424^{* *}$ & $0.592^{* *}$ & 0.133 \\
\hline $\begin{array}{l}\text { Free Choice } \\
\text { of Mate }\end{array}$ & & & 1 & $0.529^{* *}$ & $0.522^{* *}$ & $0.387^{* *}$ & $0.753^{* *}$ & 0.192 \\
\hline $\begin{array}{l}\text { Family } \\
\text { Planning }\end{array}$ & & & & 1 & $0.354^{* *}$ & $0.474^{* *}$ & $0.711^{* *}$ & 0.113 \\
\hline $\begin{array}{l}\text { Inter-Caste } \\
\text { Marriage }\end{array}$ & & & & & 1 & $0.393^{* *}$ & $0.797^{* *}$ & $\mathbf{0 . 2 5 7 ^ { * * }}$ \\
\hline $\begin{array}{l}\text { Social } \\
\text { Mobility }\end{array}$ & & & & & & 1 & $0.665^{* *}$ & $\mathbf{0 . 2 6 2 ^ { * * }}$ \\
\hline $\begin{array}{l}\text { Overall } \\
\text { Social } \\
\text { Change }\end{array}$ & & & & & & & 1 & $\mathbf{0 . 2 5 9 ^ { * * }}$ \\
\hline $\begin{array}{l}\text { Secular } \\
\text { Attitude }\end{array}$ & & & & & & & & 1 \\
\hline
\end{tabular}

(Level of significance: *0.05, **0.01)

Table 3 indicates ' $r$ ' values between social change factors and secular attitude. Inter- Caste Migration, Position of Women, Free Choice of Mate, Family Planning, Inter-Caste Marriage and Social Mobility; all these social change factors positively and strongly correlated with social change on 0.01 level of significance. Position of Women, Free Choice of Mate and Family Planning; these social change factors do not associate with secular attitude. But Inter-caste migration, Inter-caste marriage and Social mobility are positively and strongly associated with secular attitude, with ' $r$ ' values $0.242,0.257$ and 0.262 on 0.05 and 0.01 level of significance respectively. Overall social change positively correlated with secular attitude $(r=0.259)$ on 0.01 level of significance. It means that social change and secular attitude varied in the same manner. 
Figure 1

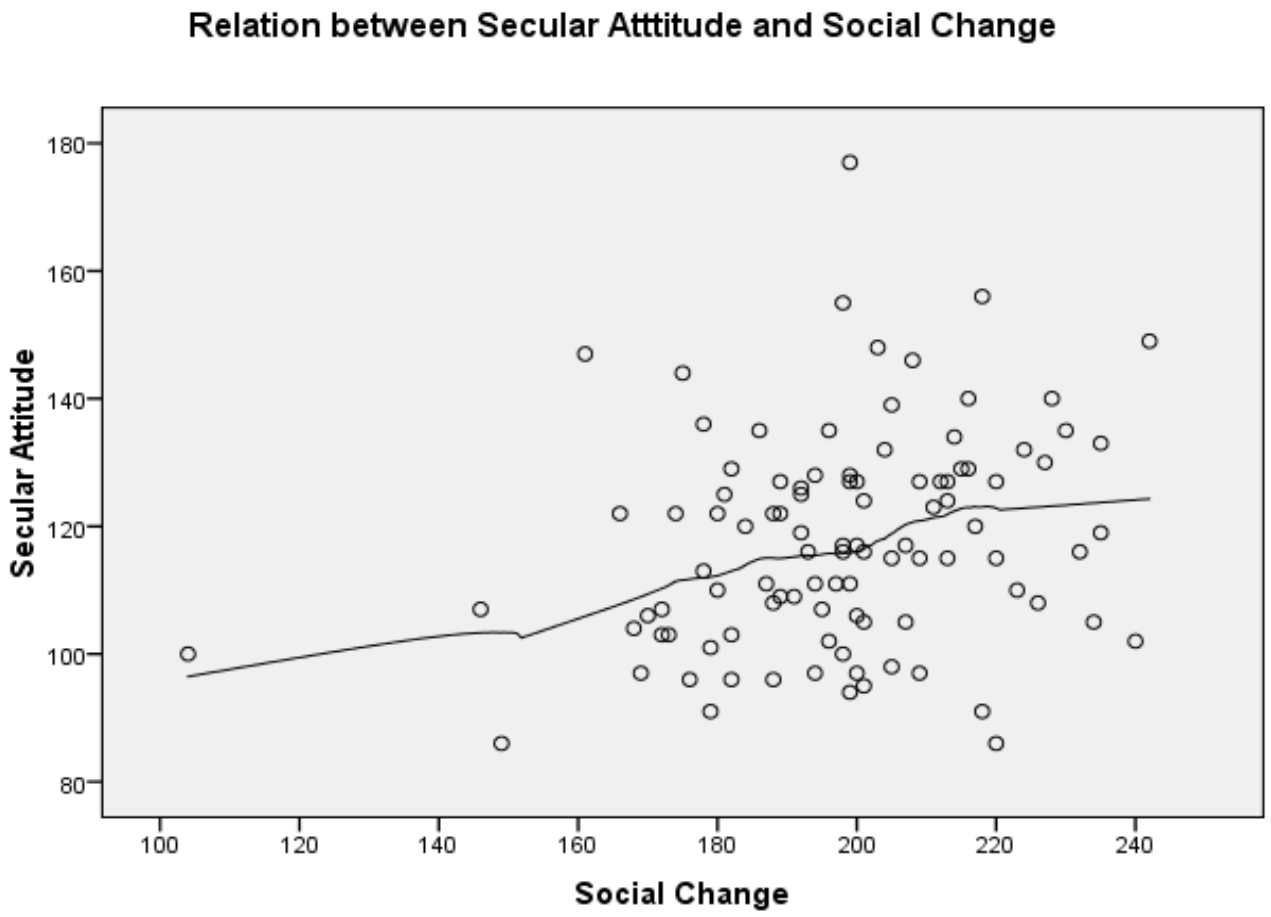

The figure 1 shows correlation between social change and secular attitude. Direction of the line shows that the relation is positive but it doesn't perfect positive. It means social change and secular attitude varied in the same manner but not strongly.

Thus the third hypothesis that, "Social change is significantly and negatively associated with secular attitude” is not accepted.

The reason of this finding may be that the existence of 'Pseudo-Secularism' in Indian society, which means that state of implicit non-secular trends in the face of pledged secularism. Though India accepted secularism by Indian Constitution, but Indians are not willing to accept it by heart. On surface they behave like a secular but non-secular attitude is existing in their unconscious. This unconscious forces came out as Godhra (Hindu's killed Muslim's overwhelmingly) and Khairlanji (five people of one lower caste family killed by higher caste people) massacre, homicide of Gandhi, Dabholkar and Pansare, social hatred towards low class and caste people, oppose to inter-caste marriages, suffering of Dalit's by atrocities, the news of Manusmriti will be written again etc. Minorities cannot be accepted in main stream. Khap Panchayati's (traditional brutal justice system) still exist; their rules and regulations are disgracing to humanity. Every religion has their own T.V. channels, Newspapers, Schools and Institutions. Thereby they influence the people, and develop non-scientific religiousness. Children get education about their parent's religion since their childhood. Politicians are spreading a separate kind of anarchism by creating religious violence, caste estrangement and regionalism. With these examples it can't say that increased social change helps promotion of secular attitude in India, but Indian society is not much more secular today, seen by present 
study. The study criticises and notifies to pseudo secularism in Indian society, and hope to change the nature for better secular India.

\section{CONCLUSIONS:}

On the basis of analysis given in previous paragraphs, it can be concluded that:

- There is no significant difference in the social change among male and female Indian youngsters.

- The male and female Indian youngsters do not have significant difference in the level of secular attitude.

- Social change is significantly and positively associated with secular attitude.

\section{SUGGESTIONS:}

1. Education of secularism must be started from school level.

2. People should accept rising social change which is helpful to upgrade society.

3. Secularism must be a part of thoughts and behaviour of people.

4. Indian Constitution must be the base of all education.

5. Researchers, social activist and government should find reasons of non-secularity and try to eradicate it.

6. Government motivates and appreciates inter-caste and inter-religion marriages, social migration and mobility.

7. Government and Funding agencies motivate researchers for search a real picture of Indian society and valuable information about secularism.

\section{REFERENCES:}

Ali, M. And Kishore, K. (2014). Secular Attitude: a study of Madarsa Students. Indian Journal of Applied Research, Vol. 4, Issue 11, 167-169

Ashrafi, M. And Govil, P. (2013). Secular Attitude of undergraduate students: A study, International Journal of Advancement in Education and Social Sciences, Vol. 1, No. 1, 26-35

Aziz, N.N., Hassan, W.H. and Saud, N.A. (2012). The effects of urbanization towards social and cultural changes among Malaysian settlers in the Federal Land Development Schemes ( FELDA ), Johor Darul Takzim. Procedia - Social \& Behavioural Sciences, Vol. 68 , 910-920

Bhargava, R. (1998). Secularism and It's Critics, Delhi: Oxford University Press

Cadez, S. (2013). Social change, institutional pressures and knowledge creation: A bibliometric analysis. Export Systems with Applications, Vol. 40, Issue 17, 6885-6893

Devis, K. (1960). Human Society, New York: International Publishers

Hashim, R.S. , Raihanah, M. M. , Hamadan, S.I., Yusuf, N.M., Abdullah, I and Amran, N.A.

(2012). Literature and Social change : Engaging Students with current issues in our Midst. Procedia - Social and Behavioral Sciences, Vol. 59, 85-89

Holyoake, G. J. (1896). The Origin and Nature of Secularism, London: Watts and Co.

Kaul, L. (2010). Methodology of Educational Research, New Delhi: Vikas Publication

Khan, K. (2009). Secularism in India, Patna 
Kuppuswamy, B. (1979). Social Change in India, Delhi: Vikas Publication

Magalingam, A. And Visvanathan, G. (2011). A study of secular attitude and attitude towards discipline among the professional college students in relation to certain selected variable, Tamilnadu: Annamalai University

Mehra, A. And Sinha, D. (1992). Manual for secular Attitude scale, Agra: National Psychological Corporation

Naik, B. (2012). The influence of gender and religion on secular attitude among college professors, Manasshastra Patrika, Vol. 20, 8-11

Naik, B. (2013). Secularism and Indian Society, Secular Vision (Marathi), Vol. 1, 25-27

Oxford Advanced Learners Dictionary (2000). $6^{\text {th }}$ Ed., New Delhi: Oxford University Press

Sankpal, S. (2012). A comparative study of social change among unmarried male and female post-graduate students, Manasshastra Patrika, Vol. 21, 50-53

Subramanyan, J. And Ajith Kumar, S. (2014). Pseudo Secularism in India, International Journal of Research in Humanities, Arts and Literature, Vol. 2, Issue 5, 7-12

Sumbul, S. (2002). A comparative study of the secular attitude of the students studying in two denominational schools, Aligarh: A.M.U.

Tiwari, R., Pandey, R. And Pal, R. (1978). Manual for A Battery Tests of Measuring Social Change, Agra: Agra Psychological Research Cell 